
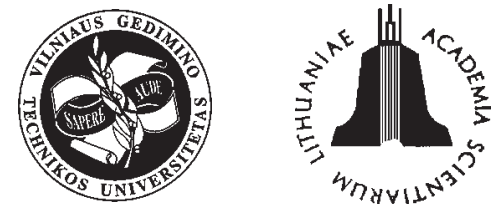

ISSN $1392-3730$

JOURNAL OF CIVIL ENGINEERING AND MANAGEMENT

http:/www.jcem.vgtu.lt

2005, Vol XI, No 3, 243-248

\title{
ABOUT THE CALCULATION OF CONCRETE ELEMENTS SUBJECTED TO LOCAL COMPRESSION
}

\author{
Vytautas Venckevičius \\ Kaunas University of Technology, Panevėžys Institute, \\ Nemuno g. 33,LT-37164 Panevéžys, Lithuania.E-mail: stk@midi.ppf.ktu.lt
}

Received 03 Feb 2004; accepted 03 Jun 2005

\begin{abstract}
The problem of calculating the local compressive strength of normal-weight concrete elements of building and engineering structures locally loaded by rigid steel plates on a small area surrounded from all sides by a non-loaded larger area of cross-section is presented in this paper. The results of experimental and theoretical investigations show that this stress-strain concentration problem is rather complicated. Therefore up to now for the determination of local compressive strength of concrete elements various calculation methods have been used. The author of this paper proposed an alternative method the algorithm of which is based on the results of statistical analysis of numerous experimental data, conclusions of adequate theoretical research and propositions of SNiP, Eurocode 2 and other design codes. According to this calculation method, the design local compressive strength of concrete and concrete elements depends not only on magnitude of local load concentration but also on characteristics of mechanical properties of concrete axial tensile and compressive strength and relative element height (ratio of element height with less line of its crosssection) too. The results of comparative calculations showed that experimental research data better comply with the calculated ones by the proposed method than with the obtained ones by SNiP, SNB, STR and Eurocode2 methods.
\end{abstract}

Keywords: normal-weight concrete elements, local compression, strength, reliability, calculation method.

\section{Introduction}

The problem of compression force action through rigid steel plates over a limited contact area of concrete surrounded from all sides by non-loaded larger area of cross-section is a frequent occurrence in normal-weight concrete elements of various building and engineering structures (eg, steel base plates of steel and reinforced concrete columns and stanchions over footings or foundations, bearings in bridge structures, etc). In this case under local load on small area $A_{c 0}$ (named as locally loaded area) the rised large local compression stresses very much depend on material layers in a larger area $A_{\mathrm{c} 1}$ - design area of local load distribution. Concrete of non-loaded zone of element acts as slander and causes the increase of concrete local compressive strength. The failure model of these concrete elements is described in [1-9].

The results of experimental and theoretical research of the author and other investigators [1, 3, 9-14] showed that the problem of stress-strain concentration is rather complicated. Therefore up to now for determinating the local compressive strength of concrete elements various calculation methods have been used. When evaluating the influence of earlier mentioned concrete slander on the local compressive strength of concrete in some of them (eg $[9,15-17]$ the attention was paid not only to the magnitude of local load concentration - ratio $R=A_{c 1}$ / $A_{c 0}$, but also to characteristics of mechanical properties of concrete - axial tensile and compressive strengths, ie, $f_{c t}$ and $f_{c}$ and in others (eg, $\left.[18,19]\right)$ - only to ratio $R$. In addition, there is no unanimous opinion on the evaluation of design area of local load distribution $A_{c 1}$.

In some calculation methods (eg [15-17], the area $A_{c 1}$ is taken symmetric to area $A_{c 0}$ and in others (eg, $[18,19])$ - similar to $A_{c 0}$. Determinated data about the ratio of element height with small line of its cross-section (relative element height) influence on the local compressive strength of concrete do not exist either. Proposition to estimate the influence of geometric parameters of element on the local compressive strength presented in [9] is based on numerous tests of concrete cubes and prisms.

It should be noted that the cube-root formula for local compression, recommended in some design codes (eg, [15]), is based on limited tests of sandstone cubes performed by Bauschinger and published in 1876 . Morsh's square-root formula, based on limited tests of normal-weight concrete cubes carried out in 1923, is recommended in German design code [19] as in Eurocode2 [18]. 
The original alternative calculation method of local compressive strength of normal-weight concrete elements which the local load acts through rigid steel plates over a small contact area surrounded by non-loaded larger area of cross-section was described in papers [1, 2, 13]. The calculation algorithm is based on the results of statistical analysis of experimental data [1,3-8], conclusions of adequate theoretical research [11, etc] and propositions of some well-known design codes [15-19]. According to this calculation method, the design local compressive strength of concrete depends not only on magnitude of local load concentration and characteristics of mechanical properties of concrete - axial tensile and compressive strengths but also on relative element height.

The results of comparative calculations showed that experimental research data better comply with the ones calculated by the author's method than with the obtained ones by SNiP, SNB, STR and Eurocode2 calculation methods.

In spite of experimental and theoretical research data (eg, [8, 20-23], etc), Eurocode2 calculation method of these concrete elements is based on propositions [24]. This is very important because technical regulations for buildings are compiled according to Eurocode2. Therefore these and similar circumstances (eg, very large difference between experimental and theoretical values of local compressive strength of concrete in case of large magnitude $R$ ) compelled the author to go back to the problem of calculating concrete elements subjected to local compression.

\section{Purposes of research}

To discuss the peculiarities of existing in design codes [15-18] and author's [2] calculation methods of the local compressive strength of concrete elements, loaded as showed in Fig 1, to compare the numerous experimental research data with the ones obtained by the above-mentioned methods and estimate the reliability of calculation by them are the main purpose of this research.

\section{Method of research}

The local compressive strength of concrete element loaded as showed in Fig 1 must be verified by the condition (common for mentioned design codes):

$$
N_{s d} \leq F_{R d u}=\alpha_{u} f_{c u d} A_{c 0},
$$

here $N_{s d}$ - design local compression force acting on the area $A_{c 0}$ and determined at the specific class of loading situation [25]; $F_{R d u}$ - design local compressive strength of concrete element; $A_{c 0}$ - loaded area of cross-section of element; $\alpha_{u}$ - coefficient to estimate the character of local load distribution on the area $A_{c 0} ; f_{c u d}$ - design local compressive strength of concrete.

The coefficient $\alpha_{u}$ value may be calculated from the condition:
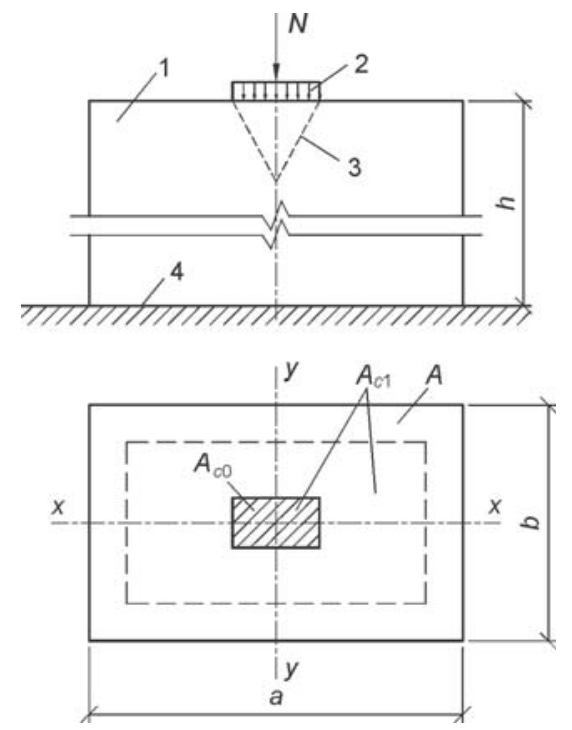

Fig 1. The design scheme of concrete element loaded by compression local load; $A_{c 0}$ - loaded area of cross-section; $A_{c 1}-$ design local load distribution area of crosssection; $A$ - general area of cross-section; 1 - element; 2 - rigid steel plate; 3 - contours of splitting pyramid [1]; 4 - surface of footing

$$
\alpha_{u}=\frac{1}{4}\left(3+\frac{\sigma_{u, \min }}{\sigma_{u, \max }}\right) \geq \frac{3}{4},
$$

here $\sigma_{u, \min }, \sigma_{u, \max }$ - the minimum and maximum of local compression stresses.

In case of uniform local load distribution $\alpha_{u}=1$.

The design value of local compressive strength of concrete

$$
f_{c u d}=\omega_{u} f_{c d},
$$

here $\omega_{u}$ - coefficient to estimate the influence of concrete slenderness which shows how many times the design local compressive strength of concrete is larger than its design cylinder compressive strength $f_{c d}$.

The theoretical values of coefficient $\omega_{u}$ are determined by expressions of calculation methods [2, 15-18].

In order to estimate the peculiarities of calculation methods of the strength here analysed concrete elements where used author's [1-8, 13] experimental data (12 party of prismatic elements made of normal-weight $\mathrm{C} 8 / 10$ C55/67 strength classes concrete). The mechanical characteristics of their concrete meet the requirements of LST EN206-1:2002. The results of comparative calculations of experimental and theoretical values of coefficient $\omega_{u}$ are presented in graphic and other form in the $5^{\text {th }}$ paragraph of this paper.

\section{Discussion of some calculation methods}

According to the SNiP design code [15], the calculation method recently used in Lithuania, value of coefficient $\omega_{u}$ must be determined by the formula 


$$
\omega_{\mathrm{u}}=\alpha \varphi_{c} \geq 1,
$$

here $\alpha$ - coefficient which shows the influence of characteristics of concrete mechanical properties:

- when concrete strength class is C20/25 and higher,

$$
\alpha=13,5 \frac{f_{c t d}}{f_{c d}},
$$

- for other concrete strength classes, $\alpha=1$; $f_{c t d}$ and $f_{c d}-$ accordingly the design values of axial tensile and compressive strengths of concrete;

$$
\varphi_{c}=\sqrt[3]{R} \leq \varphi_{c, \max }
$$

- coefficient to estimate the influence of ratio $R=A_{c 1}$ / $A_{c 0}$. When the element is loaded as in Fig 1, the limit value of this coefficient for all normal-weight concrete strength classes $-\phi_{c, \max }=2,5$. According to formulas (4)-(6), the value of the coefficient $\omega_{u}$ depends on the magnitude of local load concentration and on the mentioned characteristics of concrete mechanical properties. The design local load distribution area $A_{c 1}$ in this case is symmetric to the area $A_{c 0}$, as in Fig 2 .

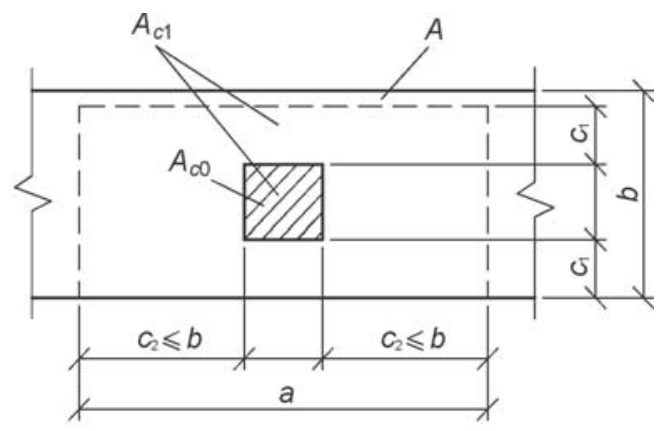

Fig 2. The scheme for calculation of design local load distribution area $A_{c 1}$ (by [15] and author)

According to the SNB [16] and STR [17] design codes calculation methods at the uniform local load distribution in the area $A_{c 0}$, the value of the coefficient $\omega_{u}$ must be determined by

$$
\omega_{u}=1+k_{u} k_{f} \frac{f_{c t d}}{f_{c d}}(\sqrt{R}-1) \leq \omega_{u, \max },
$$

here $k_{u}$ - coefficient for estimating the influence of concrete slenderness; for all normal-weight concrete strength classes

$$
k_{u}=0,8 \frac{f_{c d}}{f_{c t d}} \geq 14,0,
$$

$k_{f}$ - coefficient to estimate type of design scheme: $k_{f}=1$ (Fig 3a) and $k_{f}=0,8+0,2 \mathrm{c} / \mathrm{b}$ (Fig 3b); $\omega_{u, \max }=2,5$ independently of design scheme.

The design local load distribution area $A_{c 1}$ is symmetric to the area $A_{c 0}$ and must be determined by scheme in Fig 3. a)

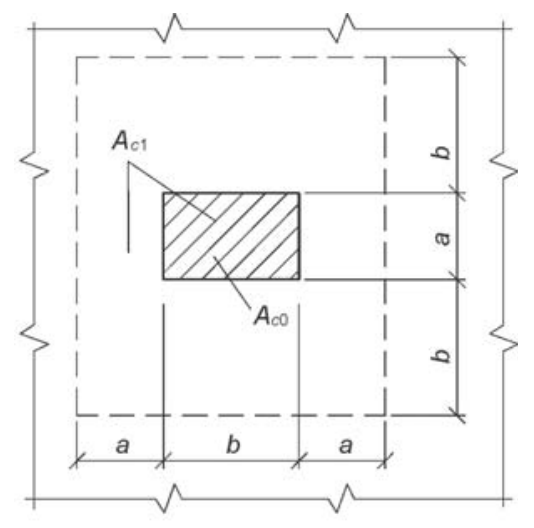

b)

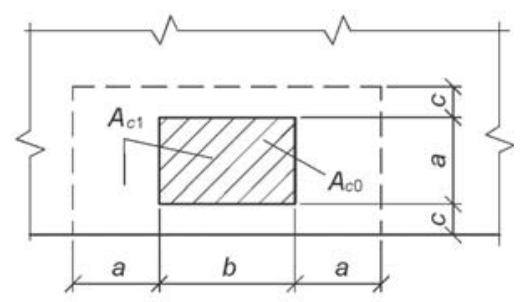

Fig 3. The scheme for calculation of design local load distribution area $A_{c 1}$ (by $[16,17]$ )

The expression for estimating of the coefficient $\omega_{u}$ in Eurocode2 [18] looks as follows:

$$
\omega_{u}=\sqrt{R} \leq \omega_{u, \max }=3,0 .
$$

In this case the design value of the coefficient $\omega_{u}$ depends only on the magnitude of local load concentration - ratio $R$. The design local load distribution area $A_{c 1}$ (Fig 4) is with a similar shape to the locally loaded area $A_{c 0}$.

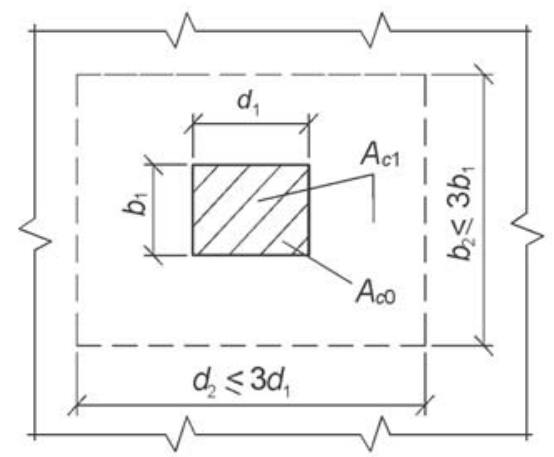

Fig 4. The scheme for calculation of design local load distribution area $A_{c 1}$ (by [18])

According to the author's $[1,2]$ calculation method, the coefficient $\omega_{u}$ must be determined by the expression:

$$
\omega_{u}=\rho\left[1+4,5 \frac{f_{c t d}}{f_{c d}}\left(\sqrt[3]{R^{2}}-1\right)\right],
$$

here $A_{c 1}$ - design local load distribution area is symmetric to the area $A_{c 0}$ (Fig 2); magnitude of local load concentration must be $R=A_{c 1} / \mathrm{A}_{c 0} \leq 60 ; 4,5$ - constant quantity; $\rho$-coefficient (Table) to estimate the influence of design relative element height - geometric parameter 
(in calculation this ratio must be less when $h / a$ or $h / b$, $a$ and $b-$ Fig 1).

Values of coefficient $\rho$

\begin{tabular}{|c|c|c|c|c|c|c|}
\hline \multirow{2}{*}{$\begin{array}{c}\text { Relative } \\
\text { element } \\
\text { height } \\
h / a \text { or } h / b\end{array}$} & \multicolumn{6}{|c|}{ Values of coefficient $\rho$ when $R$} \\
\hline & 2 & 4 & 8 & 16 & 32 & 60 \\
\hline 0,5 & 1,40 & 1,30 & 1,00 & 0,80 & 0,75 & 0,65 \\
\hline $1-4$ & \multicolumn{6}{|c|}{1} \\
\hline
\end{tabular}

Data presented in Table are based on tests of concrete prismatic elements $(h / a=h / b=0,5-4)$ performed by researchers $[1,3,4-8]$. They are suitable for concrete structural elements on a rigid footing (eg, concrete, etc).

The form of formula (10) is the same as in [1]. However, the prismatic compressive strength of concrete in it is changed by the cylinder compressive strength and mean value of constant quantity 6,15 - by the minimum value 4,5 . The values of the coefficient $n$ are the same as in [2].

In cases when ratios $h / a<1$ or $h / b<1$, these locally loaded concrete elements as flexural elements must be also calculated taking into account the properties of the material of footing (eg, concrete, soil, etc) [18, $20-23]$. Besides, such elements must be verified for punching effect too [17, 18, 20-23].

Independently of calculation method in all cases additional requirements must be satisfied:

- if on the cross-section of an element act some of the same shape local loads, the design areas $A_{c 1}$ must be limited by lines coming through the middle of distance between two contiguous local loads, ie, these areas should not overlap;

- the value $F_{R d u}$ in condition (1) must be reduced if the local load is not distributed uniformly on the area $A_{c 0}$ or if high shear forces exist.

\section{Comparison of the experimental and theoretical results}

Theoretical values of the coefficient $\omega_{u}$ were determined by calculation methods [2, 15-18] using the mean values of characteristics of mechanical properties of concrete: compressive cylinder strength $f_{c m, c y l}$ and axial tensile strength $f_{c t, m}$.

The experimental values of coefficient $\omega_{u}$ estimating the influence of concrete slander on local compressive strength of concrete were determined as follows: $\omega_{u, e}=f_{c u, m} / f_{c m, c y l}$ (here $f_{c u, m}-$ experimental value of local compressive strength of concrete). The theoretical values of this coefficient were obtained by formulas (4), (7), (9) and (10) designated according index, ie: $\omega_{u(4)}$, $\omega_{u(7)}, \omega_{u(9)}$ and $\omega_{u(10)}$. The comparison of experimental and theoretical results carried out by ratios: $\omega_{u, e} / \omega_{u(4)}$, $\omega_{u, e} / \omega_{u(7)}, \omega_{u, e} / \omega_{u(9)}$ and $\omega_{u, e} / \omega_{u(10)}$. This analysis showed such a dispersion of results: $\omega_{u, e} / \omega_{u(4)}=0,990-4,421$, $\omega_{u, e} / \omega_{u(7)}=1,020-4,272, \omega_{u, e} / \omega_{u(9)}=0,805-2,796$ and $\omega_{u, e} / \omega_{u(10)}=0,999-2,005$. Details of this calculation are presented in $[2,13]$.

These comparative results show that theoretical values of coefficient $\omega_{u(10)}$ calculated by the author's proposed method formula (10) better comply with experimental values $\omega_{u, e}$ than the obtained ones $\omega_{u(4)}, \omega_{u(7)}$ and $\omega_{u(9)}$ accordingly by SNiP method formula (4), SNB and STR methods formula (7) and Eurocode2 method formula (9).

The characteristic instance of comparison of experimental and theoretical values of coefficient $\omega_{u}$ determined by analysed calculation methods in graphic form is presented in Fig 5 (for experimental data obtained by Niyogi S.K. [8] by tests of prisms $(a \times b \times h=0,2 \times 0,2 \times 0,4 \mathrm{~m})$ made of normal-weight concrete with characteristics: $f_{\text {um }, c y l}=24,9 \mathrm{MPa}$ and $f_{c t, m}=1,93 \mathrm{MPa}$ ).

In SNiP, SNB, STR and Eurocode2 calculation methods, the influence of relative element height (in interval $0,5<h / a$ or $h / b<1$ ) on the local compressive strength of concrete is not estimated. Therefore it is reflected in results of comparative calculations presented in $[2,13]$.

It should be noted that in cases $h / a$ (or $h / b) \geq 1$, the difference between experimental and theoretical results depends on the way of estimation of design area $A_{c 1}$, characteristics of mechanical properties of concrete and magnitude $\omega_{u, \max }$. At comparatively small ratios $R$ (eg, $2-8$, etc) theoretical values $\omega_{u(7)}$ and $\omega_{u(9)}$ calculated accordingly by SNB, STR and Eurocode 2 methods exceed the experimental values. This circumstance rises doubts concerning the probability of design solutions in practice. At ratios $R=10$ and more, the results obtained by formulas (7) and (9) are reliable (Fig 5). The presented data show that in all cases of magnitude of local load concentration $R$ experimental values $\omega_{u, e}$ exceed the theoretical ones obtained by SNiP method formula (4) $-\omega_{u(4)}$. and at large values $R$ this deference increases twice and more; therefore the theoretical results are reliable but not always economical.

The values of ratio $\omega_{u, e} / \omega_{u(10)}$ show that results of calculation by proposed author's method formula (10) are reliable and their dispersion is smaller (eg, 1,0442,614 ). In addition, when relative element height is equal to one and more, this dispersion is obtained in interval $1,000-1,570$ [2]. So the results of calculation of there analysing locally loaded concrete elements by proposed method are not only more reliable but also more economical.

The possibility of application of proposed calculation method for other cases of compression local load effect (eg, strip loading, etc) may be performed by adequate research. Besides, data about the influence of characteristics of footing and type of concrete on the local compressive strength is not sufficient too. 


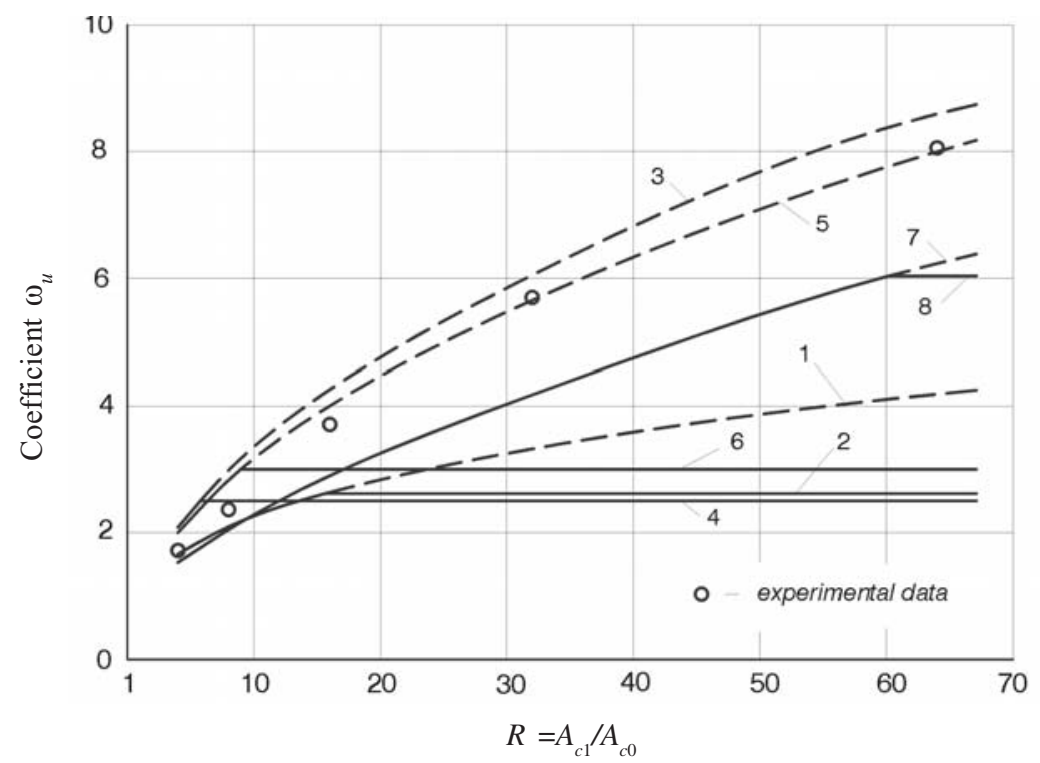

Fig 5. Comparison of experimental values of coefficient $\omega_{u, e}$ (from tests in [8]) with theoretical ones calculated: 1, 3, 5 and 7 - according to SNiP method formula, SNB and STR methods formula, Eurocode 2 method formula and proposed method formula without limitation; 2, 4, 6 and 8 - the same with limitation

\section{Conclusions}

1. The calculation of local compressive strength of concrete elements is a rather complicated stress-strain concentration problem, and its solutions are only superficial. Therefore up to now different calculation methods have been applied. When evaluating the local compressive strength of concrete in some of them (SNiP, SNB, STR), the attention is paid to magnitude of local load concentration and characteristics of mechanical properties of concrete - axial tensile and compressive strengths, and in others (eg, Eurocode2) - only on magnitude of local load concentration. According to the author's proposed calculation method, the local compressive strength of concrete, as and concrete elements being on the rigid footing (eg, concrete) depends not only on two abovementioned factors but also on ratio of element height with less line of its cross-section (relative element height).

2. The results of comparative calculations show that when concrete elements are locally loaded thought rigid steel plates on small area surrounded from all sides by a non-loaded larger area of cross-section, the experimental values of coefficient $\omega_{u}$ (as and local compressive strength of concrete) better comply with calculated ones by the author's method than the obtained ones by SNiP, SNB, STR and Eurocode2 methods: ratios of experimental and theoretical values of mentioned coefficients dispersion are in the interval 0,999-2,005 and results obtained by SNiP, SNB, STR and Eurocode2 methods accordingly - in intervals $0,990-4,421,1,020-4,272$ and $0,805-2,796$.

3 . In cases when the relative element height is less than one, these concrete elements as flexural elements must be calculated too, taking into account the properties of material of footing (eg, concrete, soil). Besides, such elements must be verified for punching effect.
4 Conclusions of this research may be applied for calculation of normal-weight concrete elements subjected to local compression. The possibility of application the method for other cases of compression local load effect (eg, strip loading, etc) including the influence of characteristics of footing and type of concrete may be performed by an adequate research.

\section{References}

1. Venckevičius, V. On the strength of concrete members subjected by the centric bearing pressure. In: Proceedings of the Higher Schools LSSR "Strength of concrete and reinforced concrete“ (Железобетонные конструкции), No 10. Vilnius, 1980, p. 83-95 (in Russian).

2. Venckevičius, V. On the calculation of bearing strength of concrete elements. In: Proceedings of the $8^{\text {th }}$ international conference "Modern building materials, structures and techniques“, May 19-21, 2004, Vilnius, Lithuania. Selected papers, ed. by E. K. Zavadskas, P. Vainiūnas and F. M. Mazzolani. Vilnius: Technika, 2004, p. 674-676.

3. Au, T. and Baird, D.L. Bearing capacity of concrete blocks. ACI Journal, Vol 56, No 9, March 1960, p. 869-880.

4. Hawkins, N. M. The bearing strength of concrete loaded through rigid plates. Magazine of Concrete Research, Vol 20, No 2, March 1968, p. 31-40.

5. Hyland, M. W. and Chen, W. F. Bearing capacity of concrete blocks. ACI Journal, Vol 67, No 3, March 1970, p. 228-236.

6. Chen, W. F. Bearing strength of concrete blocks. Journal of Engineering Mechanics Division, ASCE, Vol 99, No EM6, Dec, 1973, p. 1314-1321.

7. Niyogi, S. K. Bearing strength of concrete - geometric variations. Journal of the Structural Division, ASCE, Vol 99, No ST7, July 1973, p. 1471-1490. 
8. Niyogi, S. K. Concrete bearing strength - support, mix, size effect. Journal of Structural Division, ASCE, Vol 100, No ST8, Aug, 1974, p. 1685-1701.

9. Šleževičius, K. On the calculation of bearing strength of concrete members subjected to local compression. Reinforced concrete structures (Железобетонные конструкции), No 5. Vilnius: 1973, p. 139-153 (in Russian).

10. Kamaitis, Z. Behaviour and design of rocker bearings in bridge structures. Statyba (Civil Engineering). Vol VII, No 3. Vilnius: Technika, 2001, p. 207-212.

11. Šleževičius, K.; Roličius, J. and Mikuckis, F. Calculation of bearing elements based on theories of strength. Water Management Engineering (Vandens ūkio inžinerija), Vol 19(41). Kaunas-Akademija-Vilainiai, 2002, p. 81-85 (in Lithuanian).

12. Klemt, $\mathrm{K}$. The bearing and deformation behaviour of concrete subjected to uniaxial compressive short-time loading. Düsseldorf: VDI-Verl., 2002. 118 p.

13. Venckevičius, V. and Kaupienè, J. On the question of bearing strength of concrete. In: Proceedings of Conference Concrete and Reinforced Concrete (Konferencijos „Betonas ir gelžbetonis“ pranešimų medžiaga). Kaunas: Technologija, 2003, p. 56-62 (in Lithuanian).

14. Malakauskas, G. and Keras, V. Local pressure strength of concrete and reliability his account in norm. In: Proceedings of Conference Progressive Building (Konferencijos „Progresyvi statyba“ pranešimų medžiaga). Kaunas: Technologija, 2004, p. 71-75 (in Lithuanian).

15. SNiP 2.03.01-84*. Concrete and reinforced concrete structures. Design Code (СНиП 2.03.01 - 84*. Бетонные и железобетонные конструкции. Нормы проектирования). Moscow: CITP Gosstroja SSSR, 1989. 80 p. (in Russian).

16. SNB 5.03.01-02. Concrete and reinforced concrete structures. Design Code (СНБ 5.03.01-02 Бетонные и железобетонные конструкции. Нормы проектирования), Republika Belorus. Minsk, 2003. 139 p. (in Russian).
17. STR 2.05.05:2005. Design of concrete and reinforced concrete structures. (Betoninių ir gelžbetoniniu konstrukcijų projektavimas). Lithuanian Ministry of Environment, Vilnius, 2005. $125 \mathrm{p}$.

18. prEN 1992-1 (Final draft). Eurocode2: Design of concrete structures - Part 1: General rules and rules for buildings. CEN. B - 1050 Brussels, Oct 2001. 230 p.

19. E DIN 1045. Plain concrete, reinforced and prestressed concrete structures - Part 1: Design and construction (Tragwerke aus Beton und Stahlbeton und Spannbeton, Teil 1: Bemessung und Konstruktion), 1999 (in German).

20. Menetrey, Ph. Relationship between flexural and punching failure. ACI Structural Journal, 1998, Vol 95, No 4, p. 412-419.

21. Hallgren, M. and Bjerke, M. Non-linear finite element analysis of punching shear failure of column footings. Cement and Concrete Composites, No 24, 2002, p. 491496.

22. Vainiūnas, P.; Popovas, V. and Jarmolajev, A. Punching shear behaviour analysis of RC flat floor slab-to-column connection. Journal of Civil Engineering and Management, Vol VIII, No 2. Vilnius: Technika, 2002, p. 77-82.

23. Kollolil, J. J.; Chakrabarti, S. K. and Mishra, R. C. Experimental investigation of embedded steel plates in reinforced concrete structures. Engineering Structures, Vol 20, No 1-2, 1996, p. 105-112.

24. Euro-international Concrete Committee. International system of united technical code for building structures. Codemodel CEB-FIP for RC structures (Кодекс-образец ЕКБ - ФИП для норм по железобетонным конструкциям), 1978, Vol II. Translation from French. Moscow: NIIЮB Gosstroja SSSR, 1984. 284 p. (in Russian).

25. LST EN 1990:2004. Eurocode - Basis of structural design. (Euronormos - Statinių projektavimo pagrindai). Lithuanian Ministry of Environment. Vilnius, 2004. 71 p. (in Lithuanian).

\section{APIE BETONINIŲ ELEMENTŲ SKAIČIAVIMĄ ESANT VIETINIAM GNIUŽDYMUI}

\section{Venckevičius}

\section{Santrauka}

Nagrinejjama normaliojo betono statinių elementų, apkrautų vietine apkrova per standžias metalo plokštes mažame plote, esančiame neapkrautame didesniame plote, vietinio gniuždymo (glemžiamojo) stiprio skaičiavimo problema. Eksperimentinių ir teorinių tyrimų rezultatai rodo, kad ši ịtempių ir deformacijų problema yra gana sudètinga. Todèl betoninių elementu glemžiamajam stipriui skaičiuoti iki šiol taikomos įvairios metodikos. Siūloma skaičiavimo metodika, kurios algoritmas pagrịstas gerai žinomų gausių eksperimentinių duomenų statistinès analizès rezultatais, atitinkamų teorinių tyrimų išvadomis ir kai kurių žinomų projektavimo normų (SNiP, SBN ir kt.) nuostatomis. Skaičiuojant glemžiamus betoninius elementus pagal šią metodiką, skaičiuotinis betono glemžiamasis stipris priklauso ne tik nuo vietinès apkrovos koncentracijos didumo, bet ir nuo betono mechaninių savybių charakteristikų - ašinio tempimo ir gniuždomojo stiprių bei elemento santykinio aukščio (elemento aukščio santykio su jo skerspjūvio mažesniaja kraštine). Palyginamojo skaičiavimo rezultatai parodè, kad eksperimentinès betono, kaip ir pačių elementų, glemžiamojo stiprio reikšmès geriau atitinka apskaičiuotas pagal pasiūlytą metodiką, negu nustatytas pagal SNiP, SNB, STR ir Euronormų 2 metodikas.

Raktažodžiai: normaliojo betono elementai, vietinis gniuždymas (glemžimas), stipris, patikimumas, skaičiavimo metodika.

Vytautas VENCKEVIČIUS is Doctor, Emeritus Associate Professor at Dept of Building Technology in Panevėžys Institute of Kaunas University of Technology (KTU).

Co-author of 2 textbooks and 1 reference book, author of 8 training books and more than 50 scientific publications. Research interests; concrete and reinforced concrete elements subjected to local compression; supervision, investigation and renovation of building structures. 